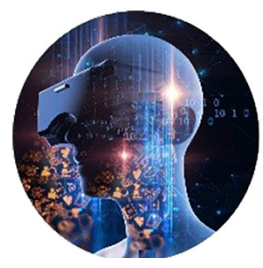

ВІЗУАЛІЗАЦІЯ ТА ІНТЕРАКТИВНІ

МУЛЬТИМЕДІЙНІ ТЕХНОЛОГІї

VISUALIZATION AND INTERACTIVE

MULTIMEDIA TECHNOLOGIES

ВИЗУАЛИЗАЦИЯ И ИНТЕРАКТИВНЫЕ

МУЛЬТИМЕДИЙНЫЕ ТЕХНОЛОГИИ

УДК 004.946:37.018.43

DOI: 10.31866/2617-796X.4.1.2021.236946

\title{
Ткаченко Ольга,
}

кандидат фрізико-математичних наук,

доцент кафедри інформачійних технологій та дизайну,

Державний університет інфраструктури та технологій,

Київ, Україна

oitkachen@gmail.com

https://orcid.org/0000-0003-1800-618X

\section{Іваницький Олександр,}

магістрант, кафедра інформаційних технологій та дизайну,

Державний університет інфраструктури та технологій,

Київ, Україна

ivanickisasha@gmail.com

https://orcid.org/0000-0003-3293-7378

\section{ВІРТУАЛЬНА РЕАЛЬНІСТЬ: НАВІГАЦІЯ У МОБІЛЬНИХ ДОДАТКАХ 3 ВИКОРИСТАННЯM GOOGLE CARDBOARD}

Метою статті є дослідження, аналіз і розгляд загальних проблем і перспектив використання систем навігації у віртуальному середовищі на мобільних пристроях з використанням окулярів віртуальної реальності Google Cardboard.

Методами дослідження $€$ методи семантичного аналізу основних понять цієї предметної сфери (системи навігації у віртуальних середовищах). У статті розглянуто наявні підходи до розробки систем навігації.

Новизною проведеного дослідження $€$ розв'язання проблем навігації у мобільних додатках, що функціонують в умовах віртуальної реальності.

Висновки. У роботі проаналізовано наявні проблеми та перспективи застосування систем навігації в мобільних додатках, що можуть бути використані у сфері гейміфікації навчання. Ураховуючи результати проведеного аналізу, розроблено систему навігації, яка має важливе значення для розв'язання проблем підвищення ефективності гейміфікації процесів навчання (особливо дистанційного, online-навчання, e-learning).

(C) Ткаченко О.І.

(c) Іваницький О. О. 
Ключові слова: мобільний пристрій; мобільний додаток; система навігації; віртуальна реальність; технології віртуальної реальності; комп'ютерна система.

Вступ. У наш час технологія віртуальної реальності є однією з перспективних інноваційних технологій (Cory, 2020).

Ідея віртуальної реальності захопила людей досить давно. Перший шолом віртуальної реальності був винайдений Ч. Уїнстоном у 1837 р.

Віртуальна реальність (Virtual Reality, VR) - створений технічними засобами штучний світ, який передається людині (користувачу) через його відчуття: зір, слух, дотик тощо.

Віртуальна реальність - це ілюзія навколишнього реального світу (дійсності), створювана за допомогою сучасних комп'ютерних систем (інформаційних, інтелектуальних), які забезпечують користувачеві зорові, звукові та інші відчуття.

Багато державних структур і підприємств (різних форм власності) з великим успіхом використовують віртуальну реальність. Сфери сучасного використання віртуальної реальності найрізноманітніші. Віртуальну реальність використовують, зокрема, у таких сферах професійної та соціокультурної діяльності людини, як:

- освіта (моделювання складної чи небезпечної діяльності, наприклад керування транспортом, проведення хімічних і фізичних дослідів тощо);

- наука (візуалізація внутрішньої структури складних об'єктів, молекулярних й атомних структур тощо);

- медицина (дистанційне й точне керування інструментами, підготовка до складних хірургічних втручань, знаходження оптимального шляху розв'язання хірургічної проблеми (підбір інструментарію, послідовності кроків оперативного втручання) тощо);

- військова справа (тренування пілотів, водіїв, операторів, підрозділів з імітацією збройних сутичок тощо);

- будівництво (побудова й редагування тривимірних моделей споруд з можливістю визначення їх технічних показників стійкості та надійності споруд тощо);

- дизайн (побудова й редагування тривимірних моделей механізмів, просторів, приміщень; симуляція та дослідження різних впливів на них);

- реклама та маркетинг (для реклами та продажу нових товарів розробляють програми, що у формі віртуальної реальності надають представлення цих товарів для більш повного уявлення про структуру та властивості товару);

- розваги та ігри (віртуальні тури, екскурсії (країнами, музеями, природничими об'єктами), віртуальні відвідування театрів, концертів, відеоігри з ефектом занурення в ігровий світ тощо).

Тому актуальність проблем, пов'язаних з розробкою сучасних систем навігації у віртуальних середовищах, не викликає сумнівів.

Під час розробки таких систем важливим є питання максимально зручної та комфортної навігації користувача у віртуальному середовищі без появи можливих негативних наслідків.

Виклад основного матеріалу. У різних системах навігації у віртуальному середовищі на мобільних пристроях особливої уваги потребують ті, що використо- 
вують окуляри віртуальної реальності Google Cardboard (https://arvr.google.com/ cardboard/; https://play.google.com/store/apps/details?id).

У 2014 р. компанія «Google» представила світу окуляри віртуальної реальноcтi Google Cardboard. Ці окуляри являють собою зібраний за схемою спеціальний пристрій (шолом) з двома оптичними лінзами, магнітом і застібками-липучками. Для повноцінної роботи пристрою слід під'єднати до нього мобільний пристрій, який працює на основі однієї з операційних систем Android, IOS або Windows Phone, із заздалегідь установленим додатком.

Популярність Google Cardboard обумовлена, зокрема, такими чинниками:

- простота створення - пристрій можна зібрати самостійно в домашніх умовах;

- невисока ціна пристрою в порівнянні з іншими шоломами віртуальної реальності.

Описані вище чинники дають змогу будь-кому зануритися у світ віртуальної реальності. Саме це й обумовлює актуальність питання розробки способів, технологій і систем навігації в цій реальності.

Більшість додатків використовують стандартну систему навігації, яку реалізувала компанія «Google» у своєму додатку Cardboard. Проте здебільшого цього не достатньо для користувачів.

Слід зазначити, що вибір способу навігації в мобільному додатку цілком і повністю залежить від виду додатку, мети розробника та цілей користувачів.

Проте незалежно від цього часто трапляються коментарі (реакції, повідомлення, зауваження) від користувачів, в яких вони просять змінити чи додати додатковий функціонал до наявної (тієї чи тієї) системи навігації.

Коментар, який зображений на рис. 1, належить мобільному додатку VR Space (https://play.google.com/store/apps/details?id). VR Space - це додаток, що $€$ у вільному доступі на ресурсі Play Market та має більше ніж 500 тис. завантажень. Коментарі користувачів здебільшого стосуються інтерфейсної частини додатку, зокрема його графіки.

g. love

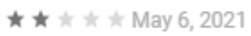

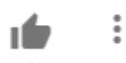

And just like that I'm bored again... Graphics good game good for like 2 minutes but nothing more add more interaction more games and you'll be on to a winner

Interesting Apps \& Games May 6, 2021

Thank you for your feedback. This demo version will become beta and later hopefully we will deliver a full game, with the support of our loyal users of course.

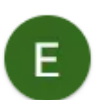

Ethan Gibbs

$\star \star \star \star \star$ March 6,2021

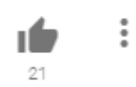

its really cool that you can shoot aliens but it will be alot funner if they would shoot back and if you could move around as you shoot

PUс 1. Коментар до додатку VR Space 
Коментар, зображений на рис. 2, стосується мобільного додатку, розробником якого є компанія «Google» і який називається Cardboard. Коментар користувача стосується як інтерфейсної частини, так і функціоналу програмної підтримки апаратного забезпечення додатку. Але незважаючи на ці незручності, додаток нараховує більше ніж 10 млн завантажень.

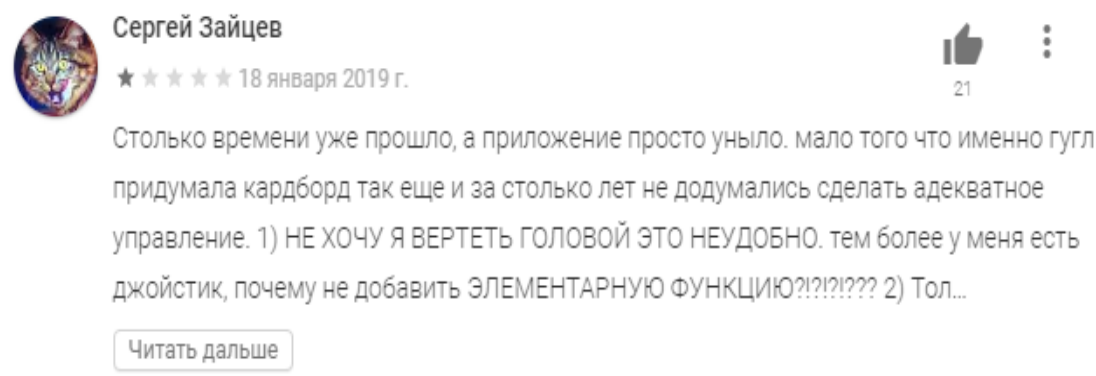

Puc 2. Коментар до додатку Cardboard

Коментар, який зображений на рис. 3, стосується мобільного додатку Kazka VR (https://play.google.com/store/apps/details?id=com.liveanimations.atbvr\&amp;hl=ru\&amp). Коментар стосується комп'ютерної гри, а оцінка користувача - інтерфейсної частини гри, але не до ії алгоритму чи дійових осіб. Цей додаток нараховує понад 1 млн завантажень.

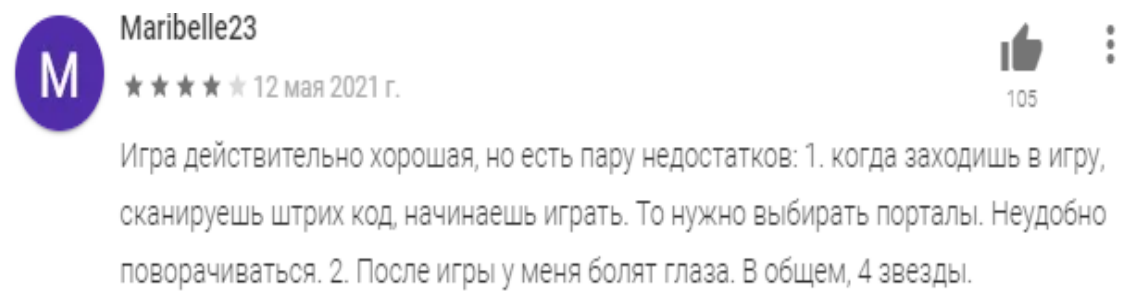

Puc 3. Коментар до додатку Kazka VR

Подібні коментарі користувачів можна побачити майже в усіх мобільних додатках, що підтримуються Cardboard. Це означає, що наявність зауважень користувачів, на які немає адекватної відповіді від розробників (бажано в короткий проміжок часу), призводить до того, що ці користувачі залишають додаток, а сам додаток втрачає безцінного клієнта.

Спроба подолання наявних недоліків перелічених мобільних додатків, хоча б у системі навігації, є актуальною проблемою, розв'язання якої сприятиме збільшенню класів завдань, які можна буде розв'язати за допомогою віртуальної реальності та розширення потенційних користувачів цих додатків.

Слід зазначити, що на ринку мобільних додатків $€$ окрема секція VR-додатків, куди йде клієнт у разі недостатньої свободи дій. Паралельно виникає таке поняття, як Motion Sickness (укр. укачування) (Семериков, 2017; Тамбовцев, 2016). 
Потужність Motion Sickness залежить від виду системи навігації, яка використовується в додатку, та поля зору, яке забезпечується.

На основі аналізу наявних систем навігації виділено, зокрема, такі види навігації (Herumurti, et el., 2017):

- навігація «польоту»;

- навігація за кліком;

- автонавігація;

- телепорт;

- змішана навігація.

Слід зазначити, що жодна з цих систем навігації не реалізує повний потенціал пересувань у віртуальній реальності, саме тому було прийнято рішення про розробку власної системи навігації (у віртуальному середовищі на мобільних пристроях з використанням окулярів віртуальної реальності Google Cardboard), яка б враховувала всі переваги інших систем, доповнюючи їх новими можливостями.

На сьогодні майже кожна людина має мобільний пристрій. Тому мобільні додатки дуже популярні. Під час розробки відповідного програмного забезпечення все більше уваги слід приділяти системам навігації у віртуальному просторі.

Розробка власної системи навігації потребує багато ресурсів, саме тому більшість мобільних додатків використовує базовий спосіб пересування, який розробила компанія «Google» та надає розробникам у вигляді вже готового пакету.

Базовий спосіб навігації являє собою пересування користувача вперед. Такий спосіб навігації часто називають «політ», адже в користувача виникає відчуття польоту. Спосіб має як і переваги, так і недоліки. Зокрема, перевагами є такі:

- просте налаштування системи навігації;

- розробник отримує вже готовий пакет з робочою системою навігації, яку можна додати до будь-якого додатку;

- використовується в більшості додатків, тому користувачу, що вже знайомий з механікою, не треба пояснювати, як пересуватися у віртуальному середовищі.

Серед недоліків слід вказати, зокрема, такі:

- обмежене пересування у віртуальному просторі;

- користувач часто відчуває проблеми, пов'язані з Motion Sickness;

- неможливість зупинитися під час пересування по віртуальному простору;

- втрата орієнтації в просторі.

Приклад використання базової навігації «політ» можна побачити в таких додатках, як Cardboard, Kazka VR, Jurassic VR (https://play.google.com/store/apps/ details?id=com.lunagames.jurassicvr\&hl). У додатках Cardboard (рис. 4) та Kazka VR (рис. 5) базова навігація являє собою політ у віртуальному середовищі.

Навігація через клік працює так: розробник задає у віртуальному просторі точки, на які користувач може натиснути. Після успішного натиску на точку, позиція користувача замінюється (згідно з алгоритмом пересування в тому чи тому додатку) на позицію точки. Такий вид пересування також є базовим способом пересування, інколи його називають «пересування по точках».

Перевагами такої системи навігації, зокрема, $€$ :

- легка імплементація; 


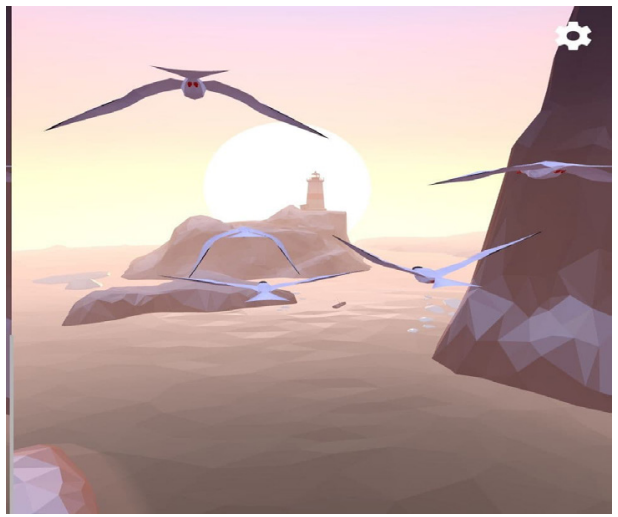

Puc. 4. Вхід у додаток Cardboard

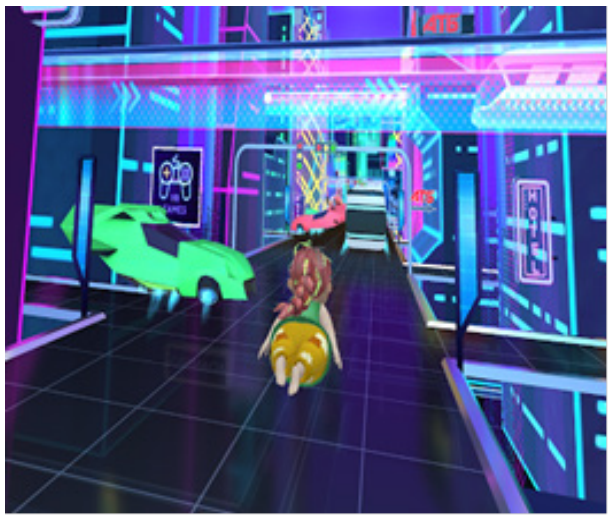

Puc. 5. Вхід у додаток Kazka VR

- використовується в багатьох додатках, тому користувачу, вже ознайомленому з механікою, не треба пояснювати, як пересуватися у віртуальному середовищі;

- не потребує залучення додаткових ресурсів для розробки системи навігації під конкретний мобільний додаток.

- Недоліками такої системи навігації, зокрема, є:

- обмежене пересування у віртуальному просторі;

- користувач часто відчуває проблему Motion Sickness;

- втрата орієнтації у віртуальному просторі;

- точки, виставлені розробником, можуть заважати інтерактивному спілкуванню з іншими об'єктами середовища.

Приклади використання зазначеної навігації можна побачити в таких додатках, як Space VR (рис. 6). Для того щоб пресуватися, потрібно натиснути на точку, що відповідає «Галактиці».

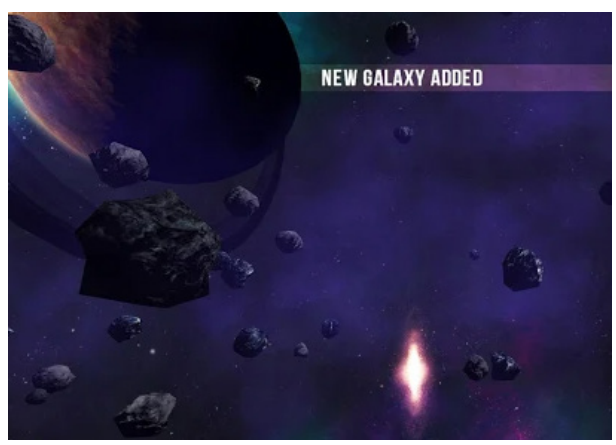

Puc 6. Вхід у додаток Space VR

Систему автонавігації також дуже часто можна побачити в мобільних VR-додатках. Користувач рухається автоматично зі швидкістю та траєкторією, яку задав розробник, до того ж можна дивитися по різних боках під час руху. Ця система навігації була однією з перших і використовується здебільшого в маленьких додатках, які реалізуються у стилі американських гірок. 
Перевагами такої системи навігації, зокрема, $є$ :

- легка імплементація;

- відсутність необхідності пояснювати користувачеві, як йому пересуватися у віртуальному середовищі;

- не потребує залучення додаткових ресурсів, щоб розробити систему навігації для конкретного мобільного додатку;

- повний контроль пересування користувача, що зменшує ймовірності різноманітних проблем (наприклад, застрягти в текстурі додатку).

Недоліками такої системи навігації, зокрема, є:

- обмежене пересування у віртуальному просторі;

- користувач часто відчуває проблему Motion Sickness;

- втрата орієнтації у віртуальному просторі;

- неможливість користувачу самостійно зупинитися під час пересування у віртуальному просторі додатку;

- складність, пов'язана з натисканням на об'єкти віртуального простору, під час пресування, якщо такі об'єкти $\epsilon$.

Приклад використання цього виду навігації можна побачити в таких додатках, як VR Thrills: Roller Coaster 360 (Cardboard Game) (рис. 7) (https://play.google. $\mathrm{com} /$ store/apps/details?id=com.rabbitmountain. rollercoaster\&hl=uk\&gl=US), InMind VR (Cardboard Game) (puc. 8.) (https://play.google.com/store/apps/details?id=com. nivalvr.inmind\&hl=ru\&gl=US).

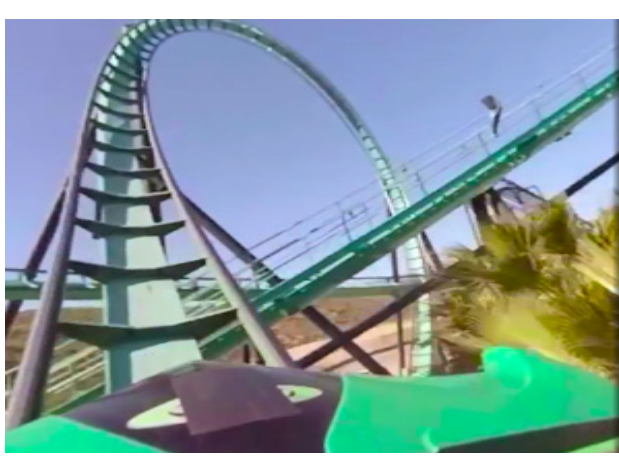

Puc. 7. Вхід у додаток VR Thrills: Roller Coaster 360 (Cardboard Game)

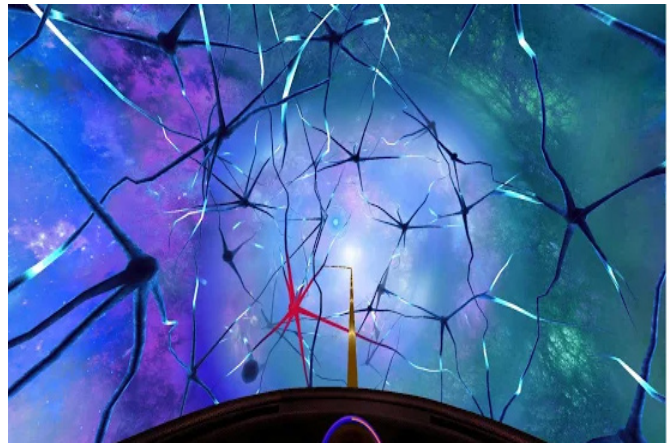

Puc. 8. Вхід у додаток InMind VR (Cardboard Game)

Систему навігації "телепорт» мало використовують через проблему Motion Sickness (Семериков, 2017; Тамбовцев, 2016). Цей тип навігації працює таким чином: користувач має натиснути на «підлогу» для телепортації в необхідне місце. Якщо часто пересуватися по віртуальному простору, то здебільшого в людей виникає сильне відчуття нудоти та біль в очах.

Перевагою такої системи навігації, зокрема, $є$ повна свобода пересування. Недоліками ж такої системи навігації, зокрема, $є$ :

- користувач сильно відчуває проблему, пов'язану з Motion Sickness;

- втрата орієнтації у віртуальному просторі; 
- потребує додаткових ресурсів для розробки системи навігації під конкретний мобільний додаток;

- можливі проблеми з інтерактивним спілкуванням з іншими об'єктами середовища.

Змішана система навігації може поєднувати в собі усі вище розглянуті види навігації. Залежно від жанру додатку розробники комбінують різні види навігації. Приклад змішаної системи навігації можна спостерігати в додатку Space VR (https://rewind.co/portfolio/bbc-home-vr-spacewalk/).

Розглянуті системи навігації не $\epsilon$ ідеальними, саме тому, проаналізувавши усі переваги та недоліки кожної з систем, було розроблено нову систему навігації у віртуальному просторі. Авторська система навігації реалізує базову систему навігації «політ» з додатковим функціоналом. Система має свій інтерфейс, який складається з таких компонентів:

- лінія інтерактиву навколо користувача (рис. 9);

- кнопка пересування (рис. 10);

- курсор (рис. 11).

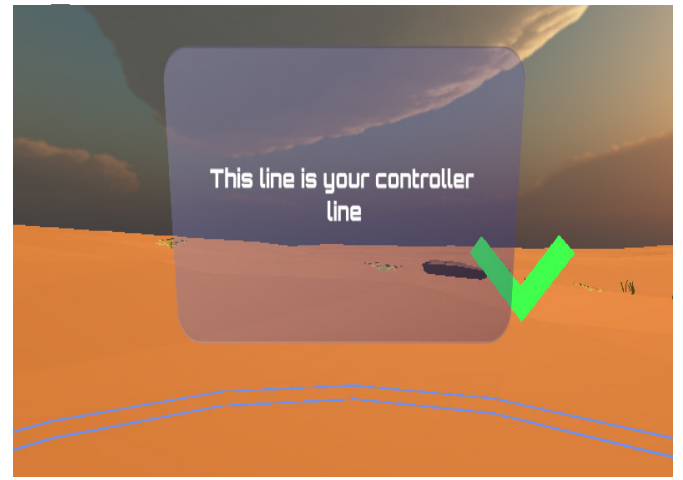

Рис. 9. Компонент «Лінія інтерактиву»

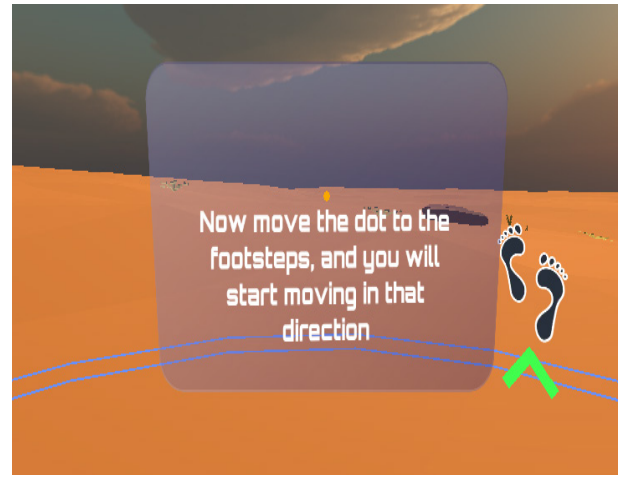

Puc. 10. Компонент «Кнопка пересування»

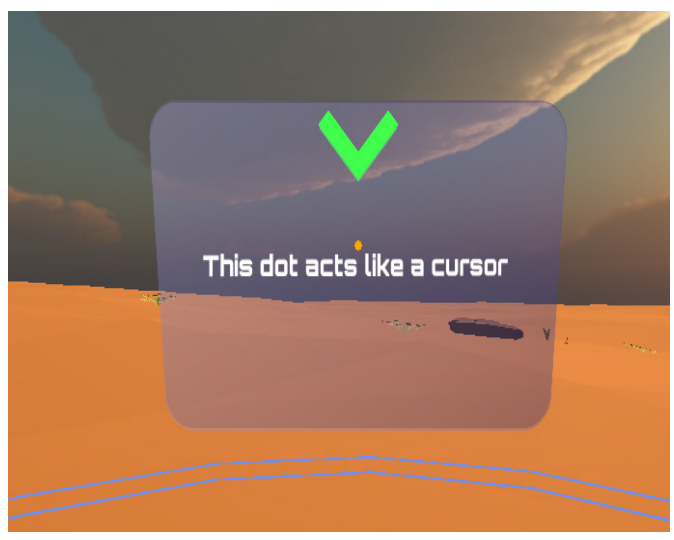

Puc. 11. Компонент «Курсор» 
Лінія навколо користувача $є$ головною частиною інтерфейсу й виконує дві ролі. По-перше, лінія допомагає користувачу не губитися у віртуальному просторі. Це запобігає виникненню відчуття дезорієнтації у просторі. По-друге, лінія $€$ об'єктом інтерактиву.

Щоб почати рухатися у просторі, користувачу потрібно навести курсор на лінію або перетнути їі. Як тільки лінія відреагувала на інтерактив, то трохи вище (справа від лінії) з'являється кнопка пересування. Якщо навести курсор на кнопку, то почнеться рух за курсором. Кнопка згодом пропадає (якщо на неї не тиснути).

Для того щоб зупинитися, потрібно перетнути лінію або навести курсор на неї. Перевагами такої системи навігації, зокрема, є:

- майже повна свобода пересування;

- мінімізація ефекту Motion Sickness;

- легка імплементація.

Основним недоліком системи, на думку авторів, є можливість появи помилок (наприклад, застрягнення в текстурі).

Варто зауважити, що на початку використання додатку користувачу слід ознайомитися із системою навігації. Компанія «Musemio» (https://www.ucl.ac.uk/ enterprise/news/2020/may/ucl-startup-musemio-brings-history-computing-alivenew-vr-game; https://www.Musemio.com) є стартапом у Сполученому Королівстві Великої Британії та Північної Ірландії. Сам додаток можна знайти на ресурсах Play Market та Арр Store під назвою Musemio (The people behind museums; Воронцов, 2016). Додаток є освітньою грою для дітей у стилі музею.

Висновки. Технологія віртуальної реальності надає нові можливості для користувачів. Наприклад, відомі фільми, такі як «Матриця», «Першому гравцю приготуватися», показують можливий потенціал технологій віртуальної реальності та способи їх використання.

Результатом розробки системи навігації $€$ її використання в мобільному додатку Musemio. Завдяки такій системі навігації компанія має договори про розробку спеціальних рівнів для благодійних організацій і навчальних закладів (https://www.forbes.com/profile/musemio/?sh=487e04518eac; https://haytorview. devon.sch.uk/a-visit-to-ancient-egypt-thanks-to-musemio/; Воронцов, 2016).

Реалізована нова система навігації в мобільному додатку Musemio демонструє величезні переваги серед інших систем навігації. Повна свобода пересування у віртуальному середовищі дає змогу користувачу насолоджуватися додатком повною мірою.

\section{СПИСОК ПОСИЛАНь}

Воронцов, Н., 2016. Ограничение поля зрения назвали средством от тошноты в виртуальной реальности. N+1. [online] Доступно: <https://nplus1.ru/news/2016/06/20/vr-motionsickness> [Дата обращения 28 мая 2021].

Семериков, И., 2017. Синдром укачивания и VR-гейминг. Почему виртуальная реальность вызывает тошноту. DTF. [online] Доступно: <https://dtf.ru/flood/3968-sindrom-ukachivaniya- 
i-vr-geyming-pochemu-virtualnaya-realnost-vyzyvaet-toshnotu> [Дата обращения 26 мая 2021].

Тамбовцев, Д., 2016. Как избежать эффекта motion sickness при перемещении в VR. Habr. [online] Доступно: <https://habr.com/ru/post/392335/> [Дата обращения 28 мая 2021].

A visit to Ancient Egypt thanks to Musemio. Haytor View Community Primary School \& Nursery. [online] 24 May 2019. Available at: <https://haytorview.devon.sch.uk/a-visit-to-ancient-egyptthanks-to-musemio/> [Accessed 25 May 2021].

Cardboard. Google Play. [online] Available at: <https://play.google.com/store/apps/details?id= com.google.samples.apps.cardboarddemo\&hl=ru\&gl=US\&showAllReviews=true> [Accessed 27 May 2021].

Cory, M., 2020. Virtual Reality. Investopedia. [online] 29 September 2020. Available at: <https:// www.investopedia.com/terms/v/ virtual-reality.asp> [Accessed 27 May 2021].

Google Cardboard - Google VR. Cardboard. [online] Available at: <https://arvr.google.com/ cardboard/> [Accessed 28 May 2021].

Herumurti D., Yuniarti, A., Kuswardayan, I., Khotimah, W.N. and Widyananda, W., 2017. Virtual reality navigation system in virtual mall environment. In: ICCIP'17: Proceedings of the 3rd International Conference on Communication and Information Processing, Tokyo. Japan, 24-26 November, [online] pp.209-213. Available at: <https://dl.acm.org/doi/10.1145/3162957.3163052> [Accessed 28 May 2021].

InMind VR (Cardboard). Google Play. [online] Available at: <https://play.google.com/store/ apps/details?id=com.nivalvr.inmind\&hl=ru\&gl=US> [Accessed 25 May 2021].

Jurassic VR - Dinos for Cardboard Virtual Reality. Google Play. [online] Available at: <https:// play.google.com/store/apps/details?id=com.lunagames.jurassicvr\&hl=uk\&gl=US> [Accessed 28 May 2021].

Kazka VR. Google Play. [online] Available at: <https://play.google.com/store/apps/details?id=com.liveanimations.atbvr\&hl=ru\&gl=US> [Accessed 26 May 2021].

Multi-Award Winning Space VR Experience. Rewind. [online] Available at: <https://rewind.co/ portfolio/bbc-home-vr-spacewalk/> [Accessed 25 May 2021].

Musemio. [online] Available at: <https://www.Musemio.com> [Accessed 23 May 2021].

Musemio. Forbes. [online] Available at: <https://www.forbes.com/profile/musemio/?sh=487e04518eac> [Accessed 23 May 2021].

Stapley-Bunten, D., 2018. Modernising museums with Musemio. Main navigation. [online] Available at: <https://startupsmagazine.co.uk/article-modernising-museums-musemio> [Accessed 23 May 2021].

The people behind museums: Kaitlin Fritz and Olga Kravchenko, Musemio. MuseumNext. [online] 18 May 2021. Available at: <https://www.museumnext.com/article/kaitlin-fritz-olga-kravchenko-musemio/> [Accessed 25 May 2021].

UCL startup Musemio brings history of computing alive with new VR game, 2020. Innovation \& Enterprise. [online] 20 May 2020. Available at: <https://www.ucl.ac.uk/enterprise/news/2020/ may/ucl-startup-musemio-brings-history-computing-alive-new-vr-game> [Accessed 23 May 2021].

VR Space. Google Play. [online] Available at: <https://play.google.com/store/apps/details?id=com.bce.VR\&hl=en_US\&gl=US> [Accessed 28 May 2021].

VR Thrills: Roller Coaster 360 (Cardboard Game). Google Play. [online] Available at: <https:// play.google.com/store/apps/details?id=com.rabbitmountain.rollercoaster\&hl=uk\&gl=US> [Accessed 26 May 2021]. 


\section{REFERENCES}

A visit to Ancient Egypt thanks to Musemio. Haytor View Community Primary School \& Nursery. [online] 24 May 2019. Available at: <https://haytorview.devon.sch.uk/a-visit-to-ancient-egyptthanks-to-musemio/> [Accessed 25 May 2021].

Cardboard. Google Play. [online] Available at: <https://play.google.com/store/apps/details?id= com.google.samples.apps.cardboarddemo\&hl=ru\&gl=US\&showAllReviews=true> [Accessed 27 May 2021].

Cory, M., 2020. Virtual Reality. Investopedia. [online] 29 September 2020. Available at: <https:// www.investopedia.com/terms/v/ virtual-reality.asp> [Accessed 27 May 2021].

Google Cardboard - Google VR. Cardboard. [online] Available at: <https://arvr.google.com/ cardboard/> [Accessed 28 May 2021].

Herumurti, D., Yuniarti, A., Kuswardayan, I., Khotimah, W.N. and Widyananda, W., 2017. Virtual reality navigation system in virtual mall environment. In: ICCIP'17: Proceedings of the 3rd International Conference on Communication and Information Processing, Tokyo. Japan, 24-26 November, [online] pp.209-213. Available at: <https://dl.acm.org/doi/10.1145/3162957.3163052> [Accessed 28 May 2021].

InMind VR (Cardboard). Google Play. [online] Available at: <https://play.google.com/store/ apps/details?id=com.nivalvr.inmind\&hl=ru\&gl=US> [Accessed 25 May 2021].

Jurassic VR - Dinos for Cardboard Virtual Reality. Google Play. [online] Available at: <https:// play.google.com/store/apps/details?id=com.lunagames.jurassicvr\&hl=uk\&gl=US> [Accessed 28 May 2021].

Kazka VR. Google Play. [online] Available at: <https://play.google.com/store/apps/details?id=com.liveanimations.atbvr\&hl=ru\&gl=US> [Accessed 26 May 2021].

Multi-Award Winning Space VR Experience. Rewind. [online] Available at: <https://rewind.co/ portfolio/bbc-home-vr-spacewalk/> [Accessed 25 May 2021].

Musemio. [online] Available at: <https://www.Musemio.com> [Accessed 23 May 2021].

Musemio. Forbes. [online] Available at: <https://www.forbes.com/profile/musemio/?sh=487e04518eac> [Accessed 23 May 2021].

Semerikov I., 2017. Sindrom ukachivaniia i VR-geiming. Pochemu virtualnaia realnost vyzyvaet toshnotu [Motion sickness syndrome and VR gaming. Why virtual reality is nauseous]. DTF. [online] Available at: <https://dtf.ru/flood/3968-sindrom-ukachivaniya-i-vr-geyming-pochemu-virtualnaya-realnost-vyzyvaet-toshnotu> [Accessed 26 May 2021].

Stapley-Bunten, D., 2018. Modernising museums with Musemio. Main navigation. [online] Available at: <https://startupsmagazine.co.uk/article-modernising-museums-musemio> [Accessed 23 May 2021].

Tambovtcev, D., 2016. Kak izbezhat effekta motion sickness pri peremeshchenii $v$ VR [How to avoid the effect of motion sickness when moving in VR]. Habr. [online] Available at: <https:// habr.com/ru/post/392335/> [Accessed 28 May 2021].

The people behind museums: Kaitlin Fritz and Olga Kravchenko, Musemio. MuseumNext. [online] 18 May 2021. Available at: <https://www.museumnext.com/article/kaitlin-fritz-olga-kravchenko-musemio/> [Accessed 25 May 2021].

UCL startup Musemio brings history of computing alive with new VR game, 2020. Innovation \& Enterprise. [online] 20 May 2020. Available at: <https://www.ucl.ac.uk/enterprise/news/2020/ may/ucl-startup-musemio-brings-history-computing-alive-new-vr-game> [Accessed 23 May 2021]. 
Vorontcov, N., 2016. Ogranichenie polia zreniia nazvali sredstvom ot toshnoty v virtualnoi realnosti [Limitation of the field of vision was called a remedy for nausea in virtual reality]. $N+1$. [online] Available at: <https://nplus1.ru/news/2016/06/20/vr-motion-sickness> [Accessed 28 May 2021].

VR Space. Google Play. [online] Available at: <https://play.google.com/store/apps/details?id=com.bce.VR\&hl=en_US\&gl=US> [Accessed 28 May 2021].

VR Thrills: Roller Coaster 360 (Cardboard Game). Google Play. [online] Available at: <https:// play.google.com/store/apps/details?id=com.rabbitmountain.rollercoaster\&hl=uk\&gl=US> [Accessed 26 May 2021].

\section{UDC 004.946:37.018.43}

\section{Tkachenko Olha,}

PhD in Physical and Mathematical Sciences,

Associate Professor, Department of Information Technologies and Design,

State University of Infrastructure and Technology,

Kyiv, Ukraine

oitkachen@gmail.com

https://orcid.org/0000-0003-1800-618X

\section{Ivanytskyi Oleksandr,}

Master's Student, Department of Information Technologies and Design,

State University of Infrastructure and Technology,

Kyiv, Ukraine

ivanickisasha@gmail.com

https://orcid.org/0000-0003-3293-7378

\section{VIRTUAL REALITY: NAVIGATION IN MOBILE APPLICATIONS WITH USING GOOGLE CARDBOARD}

The purpose of the article is to study, analyze and consider the general problems and prospects of using navigation systems in a virtual environment on mobile devices using Google Cardboard virtual reality glasses.

The research methodology consists of the methods of semantic analysis of the basic concepts of a given subject area (navigation systems in virtual environments). The article discusses the existing approaches to the development of navigation systems.

The novelty of the research is the solution of navigation problems in mobile applications that operate in virtual reality.

Conclusions. The work analyzed the existing problems and prospects for the use of navigation systems in mobile applications that can be used in the field of education gamification. Taking into account the results of the analysis, the authors have developed a navigation system that is important for solving problems of improving the effectiveness of gamification of learning processes (especially distance, online learning, e-learning).

Keywords: mobile device; mobile application; navigation system; virtual reality; virtual reality technologies; computer system. 
УДК 004.946:37.018.43

\section{Ткаченко Ольга,}

кандидат физико-математических наук,

дочент кафедры информационных технологий и дизайна,

Государственный университет инфраструктуры и технологий,

Киев, Украина

oitkachen@gmail.com

https://orcid.org/0000-0003-1800-618X

\section{Иваницкий Александр,}

магистрант, кафедра информационных технологий и дизайна,

Государственный университет инфраструктуры и технологий,

Киев, Украина

ivanickisasha@gmail.com

https://orcid.org/0000-0003-3293-7378

\section{ВИРТУАЛЬНАЯ РЕАЛЬНОСТЬ: НАВИГАЦИЯ В МОБИЛЬНЫХ ПРИЛОЖЕНИЯХ С ИСПОЛЬЗОВАНИЕМ GOOGLE CARDBOARD}

Целью статьи является исследование, анализ и рассмотрение общих проблем и перспектив использования систем навигации в виртуальной среде на мобильных устройствах с использованием очков виртуальной реальности Google Cardboard.

Методами исследования являются методы семантического анализа основных понятий данной предметной области (системы навигации в виртуальных средах). В статье рассмотрены существующие подходы к разработке систем навигации.

Новизной проведенного исследования является решение проблем навигации в мобильных приложениях, функционирующих в условиях виртуальной реальности.

Выводы. В работе были проанализированы существующие проблемы и перспективы применения систем навигации в мобильных приложениях, которые могут бить использованы в сфере геймификации обучения. Учитывая результаты проведенного анализа, была разработана система навигации, имеющая важное значение для решения проблем повышения эффективности геймификации процессов обучения (особенно дистанционного, online-обучение, е-learning).

Ключевые слова: мобильное устройство; мобильное приложение; система навигации; виртуальная реальность; технологии виртуальной реальности; компьютерная система. 